\title{
Decentralized Domestic Sewage Treatment Using an Integrated Multi-Soil-Layering and Subsurface Wastewater Infiltration System
}

\author{
Dan $\mathrm{Li}^{1}{ }^{1}$, Xinze Wang ${ }^{1, *}$, Lina Chi ${ }^{1, *} \mathbb{D}$, Zhiping Zhang ${ }^{2}$, Yanping Liu ${ }^{2}$ and Xueying $\mathrm{Li}^{2}$ \\ 1 School of Environmental Science and Engineering, Shanghai Jiao Tong University, Shanghai 200240, China; \\ 15129219131@163.com \\ 2 Yunnan Dali Research Institute, Shanghai Jiao Tong University, Dali 671000, China; \\ zhangzhiping202101@163.com (Z.Z.); yplex1230@163.com (Y.L.); 18388364019@139.com (X.L.) \\ * Correspondence: xinzewang@sjtu.edu.cn (X.W.); lnchi@sjtu.edu.cn (L.C.)
}

Citation: Li, D.; Wang, X.; Chi, L.; Zhang, Z.; Liu, Y.; Li, X. Decentralized Domestic Sewage Treatment Using an Integrated Multi-Soil-Layering and Subsurface Wastewater Infiltration System. Water 2021, 13, 431. https://doi.org/10.3390/w13040431

Academic Editor: Jose Amador Received: 24 December 2020 Accepted: 2 February 2021 Published: 7 February 2021

Publisher's Note: MDPI stays neutral with regard to jurisdictional claims in published maps and institutional affiliations.

Copyright: (c) 2021 by the authors. Licensee MDPI, Basel, Switzerland. This article is an open access article distributed under the terms and conditions of the Creative Commons Attribution (CC BY) license (https:// creativecommons.org/licenses/by/ $4.0 /)$.

\begin{abstract}
In this study, an integrated multi-soil-layering and subsurface wastewater infiltration (MSLSWI) system was developed for decentralized domestic sewage treatment under high hydraulic loading rates (HLRs). To improve sustainable nitrogen removal, the influence of intermittent operation and shunt distributing wastewater on the performance of MSL-SWI systems was investigated. The optimal performance-with removal efficiencies of $93.41 \%$ for chemical oxygen demand, $97.91 \%$ for total phosphorus, $74.02 \%$ for ammonia nitrogen, and $73.56 \%$ for total nitrogen-was achieved using both intermittent operation and shunt distributing wastewater under an HLR of $0.3 \mathrm{~m}^{3} \mathrm{~m}^{-2} \mathrm{~d}^{-1}$. The activity of microbial nitrogen functional genes (i.e., amoA, nirK, nirS, nosZ, and anammox $16 \mathrm{~S}$ rRNA) and their relationships with nitrogen transformation rates were further analyzed in different layers of the system. The results imply that nitrification and anaerobic ammonium oxidation in the MSL section coupled with nitrification and denitrification in the SWI section contribute to main the mechanisms of sustainable nitrogen removal. In summary, MSL-SWI systems not only operate with high efficiency under high HLRs, but the contaminant removal is also stable and sustainable, which are promising properties for domestic sewage treatment in areas where land resources are limited.
\end{abstract}

Keywords: multi-soil-layering system; subsurface wastewater infiltration system; nitrogen functional genes; domestic sewage treatment

\section{Introduction}

Because of limited local budgets to construct sewer networks and centralized sewage systems in small and remote communities, domestic wastewater is often discharged into the environment without treatment, resulting in serious water pollution [1,2]. Subsurface wastewater infiltration (SWI) systems have gained considerable attention in this context due to their advantages of low cost, easy maintenance, and satisfactory performance in domestic sewage treatment [3]. More than $80 \%$ of nitrogen can be removed by SWI treatments using intermittent operation and shunt distributing wastewater, with more than a 90\% removal of organic matter and phosphorus [4-6]. However, pollutant removal efficiency declines significantly when hydraulic loading rates (HLRs) are increased, and serious clogging will occur at an HLR of $0.125 \mathrm{~m}^{3} \mathrm{~m}^{-2} \mathrm{~d}^{-1}[2,7-9]$. The large operational footprints resulting from low hydraulic capacity restrict the wider application of SWI systems in areas with land resource shortages.

A novel land treatment technology, called multi-soil-layering (MSL), in which soil mixture blocks (SMBs) are surrounded by permeable layers (PLs) in a brick-like pattern, has been successfully applied under high HLRs [8,10-12]. The PLs generally consist of zeolite, gravel, or other highly porous materials. The SMBs are a mixture of local soil and other materials which can improve pollutant removal performance, such as iron with high 
phosphorus adsorption capacity, sawdust frequently used as a solid carbon source for nitrogen removal, etc. This basic structure improves the dispersion of water and reduces the risk of clogging effectively $[13,14]$. Therefore, MSL systems can operate well with favorable performance, even with HLRs 5-10 times that of SWI systems [15-18]. Studies of MSL systems for domestic wastewater treatment in recent years mainly focus on the substrate composition improvement and operation mode optimization [19-22]. However, owing to the inhomogeneous structure of substrate, the effluent quality of MSL systems fluctuates more violently than SWI systems, which has potential risks to the environment. In addition, unsustainable denitrification with low efficiency relying on the extra solid carbon source addition in SMBs is also a problem that needs to be solved [14,15].

In this study, a two-stage system consisting of MSL and SWI (termed MSL-SWI) was developed to make them complement each other and achieve stable and sustainable purification performance for domestic sewage treatment under high HLRs. The wastewater was first fed into an upper MSL section to reduce the pollutant loading and mitigate clogging during the following SWI section which was designed to further remove pollutants. To improve durable nitrogen removal, intermittent operation that ensures the favorable aerobic conditions for nitrification and shunt distributing wastewater instead of using additional solid carbon sources for denitrification was utilized in MSL-SWI systems. This paper focuses on pilot-scale experiments in four MSL-SWI systems treating domestic wastewater under high HLRs. The purification performances with respect to chemical oxygen demand (COD), total phosphorus (TP), ammonia nitrogen $\left(\mathrm{NH}_{4}-\mathrm{N}\right)$, nitrite nitrogen $\left(\mathrm{NO}_{2}-\mathrm{N}\right)$, nitrate nitrogen $\left(\mathrm{NO}_{3}-\mathrm{N}\right)$, and total nitrogen $(\mathrm{TN})$ were compared using mid-stage and final effluent in four different setups. To determine the nitrogen removal mechanisms in MSL-SWI systems, key nitrogen removal functional genes (amoA, nirK, nirS, nosZ, and anammox $16 \mathrm{~S}$ rRNA) were analyzed in the different media, which were correlated with the migration and transformation of nitrogen.

\section{Materials and Methods}

\subsection{Experimental Apparatus and Materials}

Four setups (Figure 1a) made of stainless steel were constructed outdoors and were operated under different conditions at a sewage treatment plant in Dali, Yunnan Province, China. The MSL section ( $50 \mathrm{~cm}$ length $\times 50 \mathrm{~cm}$ width $\times 70 \mathrm{~cm}$ height) consisted of soil mixture layers (SMLs) alternating with PLs, as shown in Figure 1b. Each SMB in the SMLs was filled with the same substrate, composed of $60 \%$ local soil, $30 \%$ cinder, and $10 \%$ bio-ceramic by weight. Additionally, two different SMB dimensions were used- $12.5 \mathrm{~cm}$ length $\times 50 \mathrm{~cm}$ width $\times 5 \mathrm{~cm}$ height and $15 \mathrm{~cm}$ length $\times 50 \mathrm{~cm}$ width $\times 5 \mathrm{~cm}$ height. The void space between the vertically and horizontally adjacent SMBs was filled with zeolite particles with diameters of $0.1-0.3 \mathrm{~cm}$. A $5 \mathrm{~cm}$ layer of gravel $(1-3 \mathrm{~cm}$ diameter) was prepared at the surface and bottom level of each system. Influent emitter pipes were installed at the top of the MSL systems. The dimension of the SWI section (Figure 1c) was the same as the MSL systems. Each cuboid was filled with $10 \mathrm{~cm}$ of gravel (1-3 mm diameter) at the top and bottom. A homogeneous substrate, composed of $70 \%$ local soil, $20 \%$ cinder, and $10 \%$ bio-ceramic by weight, was placed in the middle of each SWI system. The SWI section was fed by treated wastewater from the MSL section, and the influent emitter for the SWI was installed at the bottom to increase the hydraulic retention time. 
(a)
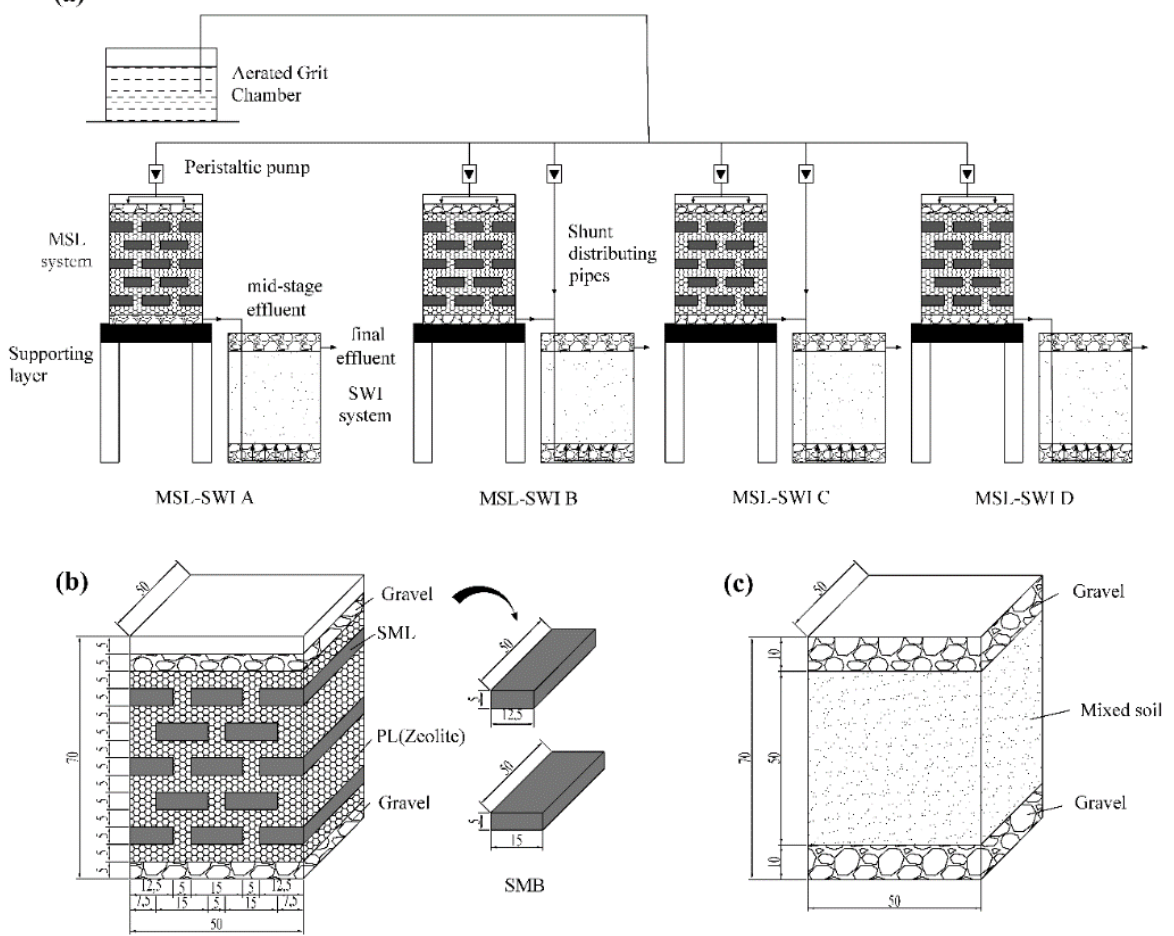

Figure 1. Schematic drawing of the experimental apparatus: (a) four multi-soil-layering and subsurface wastewater infiltration (MSL-SWI) systems with different operation modes; (b) the MSL section; (c) the SWI section. Note: All dimensions are shown in $\mathrm{cm}$.

\subsection{System Operation}

Real domestic wastewater was discharged into each MSL-SWI system by peristaltic pumps. The wastewater quality indexes were as follows: COD $=74.5-139.2 \mathrm{mg} \mathrm{L}^{-1}$, $\mathrm{TP}=1.7-5.8 \mathrm{mg} \mathrm{L}^{-1}, \mathrm{TN}=22.2-34.2 \mathrm{mg} \mathrm{L}^{-1}$, and $\mathrm{NH}_{4}-\mathrm{N}=9.2-19.1 \mathrm{mg} \mathrm{L}^{-1}$.

Four setups operated under different conditions were constructed in this study, named MSL-SWI A, B, C, and D. The HLR of MSL-SWI A, B, and C was the same, namely, $0.3 \mathrm{~m}^{3} \mathrm{~m}^{-2} \mathrm{~d}^{-1}$. MSL-SWI A was a control with continuous feeding. Shunt distribution pipes were installed and connected with the outlet pipe of MSL sections to supply shunt distributed wastewater to SWI sections of MSL-SWI B and C. The main distributing pipe and the shunt distributing pipe had HLRs of $0.2 \mathrm{~m}^{3} \mathrm{~m}^{-2} \mathrm{~d}^{-1}$ and $0.1 \mathrm{~m}^{3} \mathrm{~m}^{-2} \mathrm{~d}^{-1}$, respectively. An intermittent operation mode was also applied in the case of MSL-SWI C, whereby each cycle included a flooding period of $12 \mathrm{~h}$ and a drying period of $12 \mathrm{~h}$. Feeding began at 8 a.m. and was stopped at 8 p.m. each day. Lastly, to study the influence of higher HLRs, a fourth system (MSL-SWI D) was fed continuously at an HLR of $0.5 \mathrm{~m}^{3} \mathrm{~m}^{-2} \mathrm{~d}^{-1}$. Specific operating parameters of the four MSL-SWI systems are shown in Table 1.

Table 1. Operating parameters of four MSL-SWI systems operated under different modes.

\begin{tabular}{ccccccccc}
\hline Operation Modes & \multicolumn{2}{c}{ A } & \multicolumn{2}{c}{ B } & \multicolumn{2}{c}{ C } & \multicolumn{2}{c}{ D } \\
\hline $\begin{array}{c}\text { HLR } \\
\left(\mathrm{m}^{3} \mathrm{~m}^{-2} \mathrm{~d}^{-1}\right)\end{array}$ & 0.3 & 0.3 & 0.2 & 0.3 & 0.2 & 0.3 & 0.5 & 0.5 \\
$\begin{array}{c}\text { Operation time } \\
\left(\mathrm{h} \mathrm{d}^{-1}\right)\end{array}$ & 24 & 24 & 24 & 24 & 12 & 12 & 24 & 24 \\
$\begin{array}{c}\text { Flow rate } \\
\left(\mathrm{cm}^{3} \text { min }^{-1}\right)\end{array}$ & 52.08 & 52.08 & 34.72 & 52.08 & 69.44 & 104.17 & 86.81 & 86.81 \\
\hline 1 Flow rate at runtime. & & & & & & & & \\
\hline
\end{tabular}


The red clay used in the systems was taken from the top $20 \mathrm{~cm}$ of earth in Dali, Yunnan Province, China; the zeolite was purchased from the Zhejiang Shenshi Mining Industry Co., Ltd. (Wenzhou, China); the cinder was collected from the Midu Lixin Engineering Construction Co., Ltd. (Dali, China); and the biological ceramsite was obtained from bioceramic, which was purchased from the Gongyi Longxin Water Purification Material Co., Ltd. (Zhengzhou, China). For fundamental properties of materials, refer to Appendix A.

\subsection{Water Sampling and Analysis}

Water samples from the influent, mid-stage effluent, and final effluent were taken from the aerated grit chambers, the outlet pool in the MSL section, and the outlet pools in the SWI section, respectively, every five days at 11 a.m. The collected samples were stored at $4{ }^{\circ} \mathrm{C}$ and analyzed within $24 \mathrm{~h}$. The quality analysis methods were as follows: the potassium dichromate method was used to determine COD; the colorimetric method was used to determine $\mathrm{TP}, \mathrm{NH}_{4}-\mathrm{N}$, and $\mathrm{NO}_{2}-\mathrm{N}$; and the ultraviolet spectrophotometric method was used to determine $\mathrm{NO}_{3}-\mathrm{N}$ and TN. All of the techniques followed standard methods [23].

\subsection{Soil Sampling and Determination}

Matrix samples were collected from PLs, SMBs, and SWI sections of the four setups. The samples were then stored in an ice incubator and subsequently brought to the laboratory for nitrogen mass balance and key nitrogen removal functional gene analyses.

Total nitrogen in the matrix was determined by the potassium dichromate-sulfuric acid digestion method [24]. The gene detection was based on the qPCR technique according to Ji et al. [25]. MIO-BIO power Soil DNA isolation kits were used to extract and purify the total genomic DNA from the samples. Extracted genomic DNA was detected by $1.2 \%$ agarose gel electrophoresis. Quantitative analysis was conducted on target fragments of the amoA, nirK, nirS, and nosZ genes and anammox 16S rRNA (AMX). Primers for these gene fragments were synthesized, and standard curves of the abundance of nitrogen micro-cycle functional genes were quantitated. The $\mathrm{r}^{2}$ value of each standard curve was greater than 0.99. The qPCR was performed on an FTC-3000 Real-Time PCR detection system (Funglyn Biotech, Canada) using SYBR Green as the fluorescent dye in a three-step thermal cycling procedure, and each real-time PCR amplification consisted of a total of 40 cycles. Sterile water was used as a negative control, at which point the absolute richness of the genes was measured.

\subsection{Statistical Analysis}

The concentrations of the influent, the mid-stage effluent, and the final effluent were used to calculate the transformation rates of nitrogen in the MSL and SWI sections of the MSL-SWI systems. The additional pollution from the shunt distributed wastewater was considered in the calculation of the SWI nitrogen transformation rates of MSL-SWI B and $\mathrm{C}$. The association between the nitrogen removal rate and the abundance of key nitrogen functional genes was assessed using correlation analysis in SPSS 20.

\section{Results}

\subsection{Organic Matter Removal}

The average water quality and removal efficiency of mid-stage and final effluents are presented in Table 2. The COD removal performance of four MSL-SWI systems during the entire experimental period is shown in Figure 2. In a soil infiltration system, physicochemical reactions such as filtration and adsorption are considered the major initial processes of organic matter removal, which are gradually replaced by microbial action over time $[11,26]$. Generally, the period for the establishment of a stable physical, chemical, and biological environments is considered as the "start-up" of soil infiltration treatments, during which the effluent quality fluctuates significantly. As shown in Figure 2, the COD removal efficiency as measured for both mid-stage and final effluents in four systems remained stable after the 20-day experiment, which could be considered as the completion of the start-up period. 
Table 2. Performance of MSL-SWI systems under various operating conditions.

\begin{tabular}{|c|c|c|c|c|c|c|c|c|c|}
\hline \multirow[b]{2}{*}{ Para-Meters } & \multirow[b]{2}{*}{ Influent } & \multicolumn{2}{|c|}{ MSL-SWI A } & \multicolumn{2}{|c|}{ MSL-SWI B } & \multicolumn{2}{|c|}{ MSL-SWI C } & \multicolumn{2}{|c|}{ MSL-SWI D } \\
\hline & & $\begin{array}{c}\text { Mid-Stage } \\
\text { Effluent }\end{array}$ & $\begin{array}{c}\text { Final } \\
\text { Effluent }\end{array}$ & $\begin{array}{l}\text { Mid-Satge } \\
\text { Effluent }\end{array}$ & $\begin{array}{c}\text { Final } \\
\text { Effluent }\end{array}$ & $\begin{array}{c}\text { Mid-Stage } \\
\text { Effluent }\end{array}$ & $\begin{array}{c}\text { Final } \\
\text { Effluent }\end{array}$ & $\begin{array}{c}\text { Mid-Satge } \\
\text { Effluent }\end{array}$ & $\begin{array}{c}\text { Final } \\
\text { Effluent }\end{array}$ \\
\hline $\mathrm{COD}_{\mathrm{cr}}$ & $107.1 \pm 20.2^{1}$ & $9.79 \pm 4.06(90.45)^{2}$ & $5.98 \pm 2.15(94.24)$ & $7.69 \pm 4.59(92.46)$ & $7.05 \pm 2.95(93.35)$ & $8.03 \pm 3.72(92.32)$ & $6.91 \pm 2.52(93.41)$ & $\begin{array}{c}14.18 \pm 7.68 \\
(85.52)\end{array}$ & $8.21 \pm 3.28(91.95)$ \\
\hline $\mathrm{NH}_{4}-\mathrm{N}$ & $13.10 \pm 2.97$ & $0.60 \pm 0.65(95.42)$ & $0.33 \pm 0.29(97.36)$ & $0.18 \pm 0.15$ (98.53) & $4.48 \pm 1.31(66.12)$ & $0.23 \pm 0.20(98.22)$ & $3.43 \pm 1.02(74.02)$ & $0.32 \pm 0.20(97.46)$ & $0.25 \pm 0.15(97.98)$ \\
\hline $\mathrm{NO}_{3}-\mathrm{N}$ & $0.65 \pm 0.26$ & $15.62 \pm 2.92$ & $14.51 \pm 3.59$ & $19.45 \pm 3.62$ & $5.26 \pm 1.29$ & $15.88 \pm 3.84$ & $2.88 \pm 1.20$ & $4.83 \pm 2.43$ & $2.40 \pm 1.40$ \\
\hline $\mathrm{NO}_{2}-\mathrm{N}$ & $0.11 \pm 0.054$ & $0.005 \pm 0.013$ & $0.008 \pm 0.017$ & $0.057 \pm 0.013$ & $0.22 \pm 0.09$ & $0.043 \pm 0.054$ & $0.262 \pm 0.247$ & $0.065 \pm 0.067$ & $0.049 \pm 0.105$ \\
\hline $\mathrm{TN}$ & $27.97 \pm 3.85$ & $18.16 \pm 4.16(36.99)$ & $17.41 \pm 4.64$ (38.08) & $21.50 \pm 4.35(22.19)$ & $10.96 \pm 1.18(60.55)$ & $17.44 \pm 5.33(36.92)$ & $7.39 \pm 1.34(73.56)$ & $7.29 \pm 3.54(74.16)$ & $4.53 \pm 2.10(84.13)$ \\
\hline
\end{tabular}

${ }^{1}$ Mean value \pm standard deviation $(\mathrm{mg} / \mathrm{L}) .{ }^{2}$ Values in the round brackets represent the mean removal efficiency $(\%)$. 

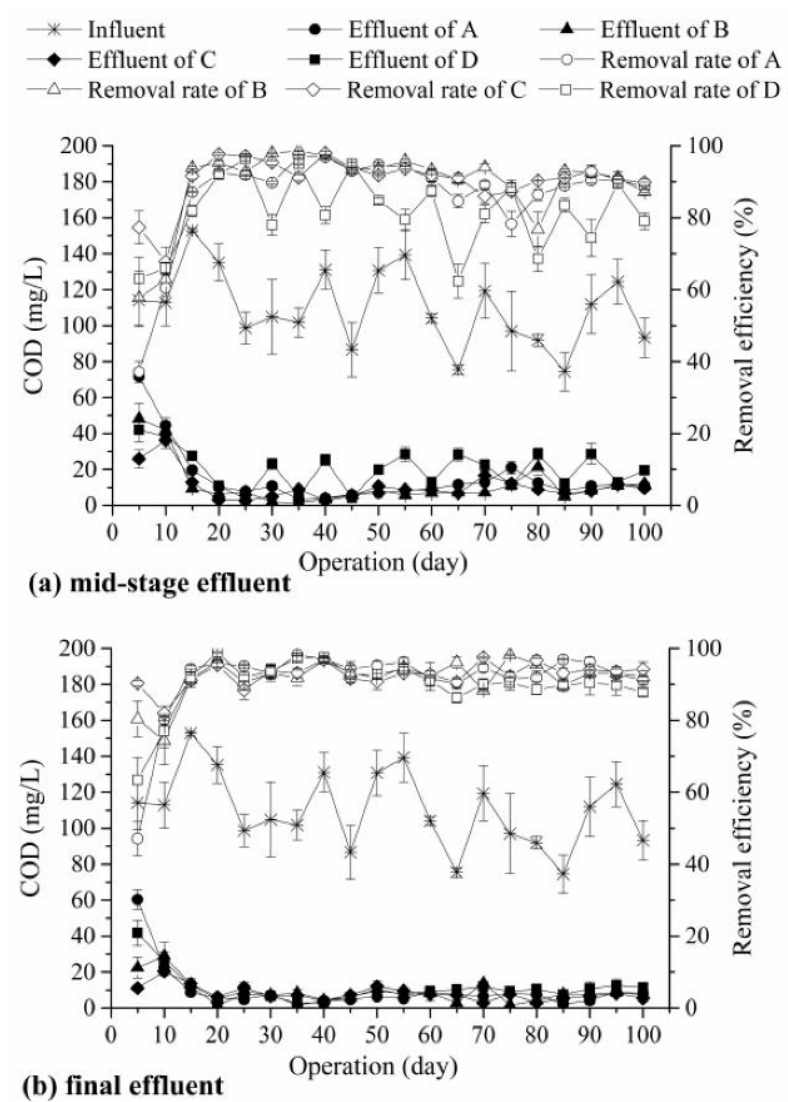

Figure 2. COD concentrations and removal efficiencies in different experimental MSL-SWI systems. (a): COD in mid-stage effluent; (b): COD in final effluent.

After the start-up period, the COD concentrations of the mid-stage effluent in MSLSWI A, B, C, and D were $9.79 \pm 4.06 \mathrm{mg} \mathrm{L}^{-1}, 7.69 \pm 4.59 \mathrm{mg} \mathrm{L}^{-1}, 8.03 \pm 3.72 \mathrm{mg} \mathrm{L}^{-1}$, and $14.18 \pm 7.68 \mathrm{mg} \mathrm{L}^{-1}$ and the average removal efficiencies were $90.45 \%, 92.46 \%, 92.32 \%$, and $85.52 \%$, respectively. In MSL systems, organic matter degradation occurs mainly in the upper layer by aerobic biochemical oxidation [11,13]. It is indicated that the average COD removal efficiency decreased with the increment of HLRs in MSL sections through the comparation of the mid-stage effluents of systems A, B, and D. More oxygen will be consumed by biological degradation under larger pollutant inputs, which is adverse to the aerobic environments and constrains the COD removal process [27]. With regard to MSL-SWI B and C, both with an MSL HLR of $0.2 \mathrm{~m}^{3} \mathrm{~m}^{-2} \mathrm{~d}^{-1}$, there were no significant differences between the COD values $(p>0.05)$. The favorable aerobic conditions contributed by the MSL structure facilitated the formation of a satisfactory aerobic environment, and the intermittent operation showed a limited improvement in COD removal. In addition, as shown in Figure 2a, COD removal efficiency fluctuated greatly during the middle and later periods in MSL-SWI D when compared to the other systems. Sato et al. reported that the efficiency of organic matter removal was higher in the SMBs than in the PLs because of more effective interception and degradation in the mixed soil $[10,11]$. Accordingly, it could be inferred that "short-circuiting" occurred in MSL-SWI D under the higher HLR of $0.5 \mathrm{~m}^{3} \mathrm{~m}^{-2} \mathrm{~d}^{-1}$, whereby sewage flowed along the PLs, leading to unstable COD removal.

Nevertheless, after further purification by the mixed soil of the SWI systems, the removal efficiency of COD based on the final effluent reached $94.24 \%, 93.35 \%, 93.41 \%$, and $91.95 \%$ in MSL-SWI A, B, C, and D, respectively. Although the SWI sections were saturated in this study, the purification efficiency increased in all systems, even when shunt distributed wastewater was added to MSL-SWI B and C. This could be explained by anaerobic degradation by heterotrophic bacteria in the SWI sections, including denitrifying processes that consume organic matter as a carbon source $[28,29]$. The COD concentrations 
of the final effluents in four MSL-SWI systems were stable and had no obvious differences $(p>0.05)$.

\subsection{Phosphorus Removal}

Physicochemical sedimentation and adsorption are the main pathways of phosphorus removal in soil infiltration systems, and occur simultaneously [30,31]. As shown in Figure 3, excellent TP removal efficiencies (of more than 95\%) were observed for the mid-stage and final effluents in all four MSL-SWI systems at the start of their operation. However, TP concentrations in the mid-stage effluents of MSL-SWI A and D fluctuated during the middle and later periods, especially in system D, as shown in Figure 3a. In MSL systems, the removal of phosphorus depends more on water infiltrating into the SMBs than the PLs $[10,11]$. Therefore, the phenomenon provided further evidence of the "short-circuiting" of water flow in system A and system D, resulting in lower TP removal efficiencies of $94.17 \%$ and $85.85 \%$, respectively. In the other systems, the purification performance was significantly better and remained relatively stable.

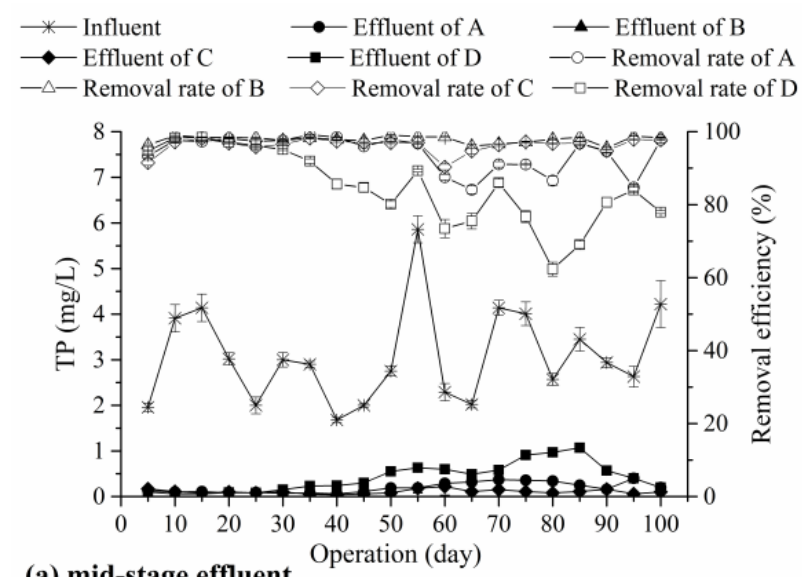

(a) mid-stage effluent Operation (day)

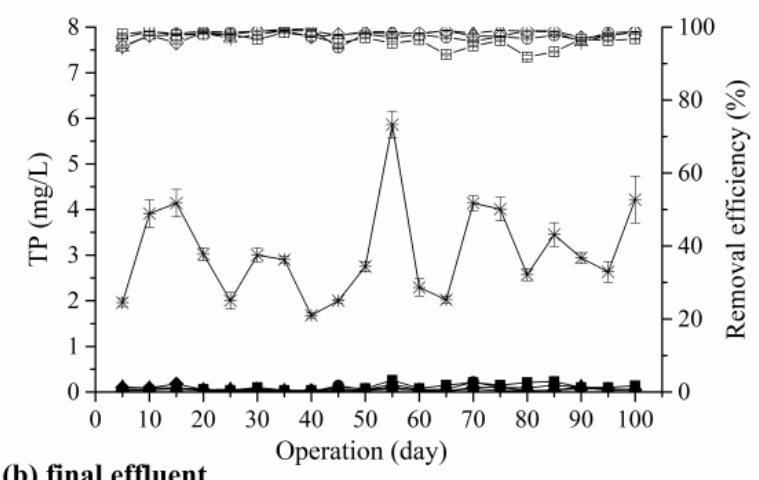

(b) final effluent

Figure 3. Concentrations of TP and removal efficiencies in different experimental MSL-SWI systems. (a): TP in mid-stage effluent; (b): TP in final effluent.

Similar to COD removal, after purification by SWI sections, the TP concentrations in the final effluents were consistently less than $0.20 \mathrm{mg} \mathrm{L}^{-1}$ in all systems. Shunt distributing wastewater in MSL-SWI B and C displayed no obvious effects on phosphorus removal, resulting from the high phosphorus removal capacity of the SWI substrates (such as red clay and cinder) which contain large amounts of iron and alumina oxides [9,32].

\subsection{Nitrogen Removal}

Nitrogen removal processes were established over time in the four MSL-SWI systems, as shown in Figure 4. In soil infiltration systems, the removal of $\mathrm{NH}_{4}-\mathrm{N}$ is dominated by adsorption and nitrification $[13,19,33]$. Based on the mid-stage effluent, excellent removal 
efficiencies of more than $95 \%$ were achieved from the beginning of the experiment, and there were no significant differences between the four systems $(p>0.05)$. The high ion exchange capacity of zeolites in the PLs was the predominant contributor to the results. Based on the final effluents from SWI sections, the excellent purification performances were maintained in MSL-SWI A and D. However, due to the addition of shunt distributed wastewater, it took approximately 35 days to reach a relatively stable performance in MSLSWI B and C, and the removal efficiency decreased by $32.41 \%$ and $24.20 \%$, respectively. This indicated the lower $\mathrm{NH}_{4}-\mathrm{N}$ adsorption property of the mixed soil, and the limited nitrification owing to the saturated anaerobic condition in the SWI section. In contrast, the higher removal efficiency in MSL-SWI C showed positive effects of intermittent operation, as was found by Li et al. [34].

$\longrightarrow$ Influent $\longrightarrow$ Effluent of A $\neg$ Effluent of B $\rightarrow$ Effluent of $\mathrm{C} \longrightarrow$ Effluent of D
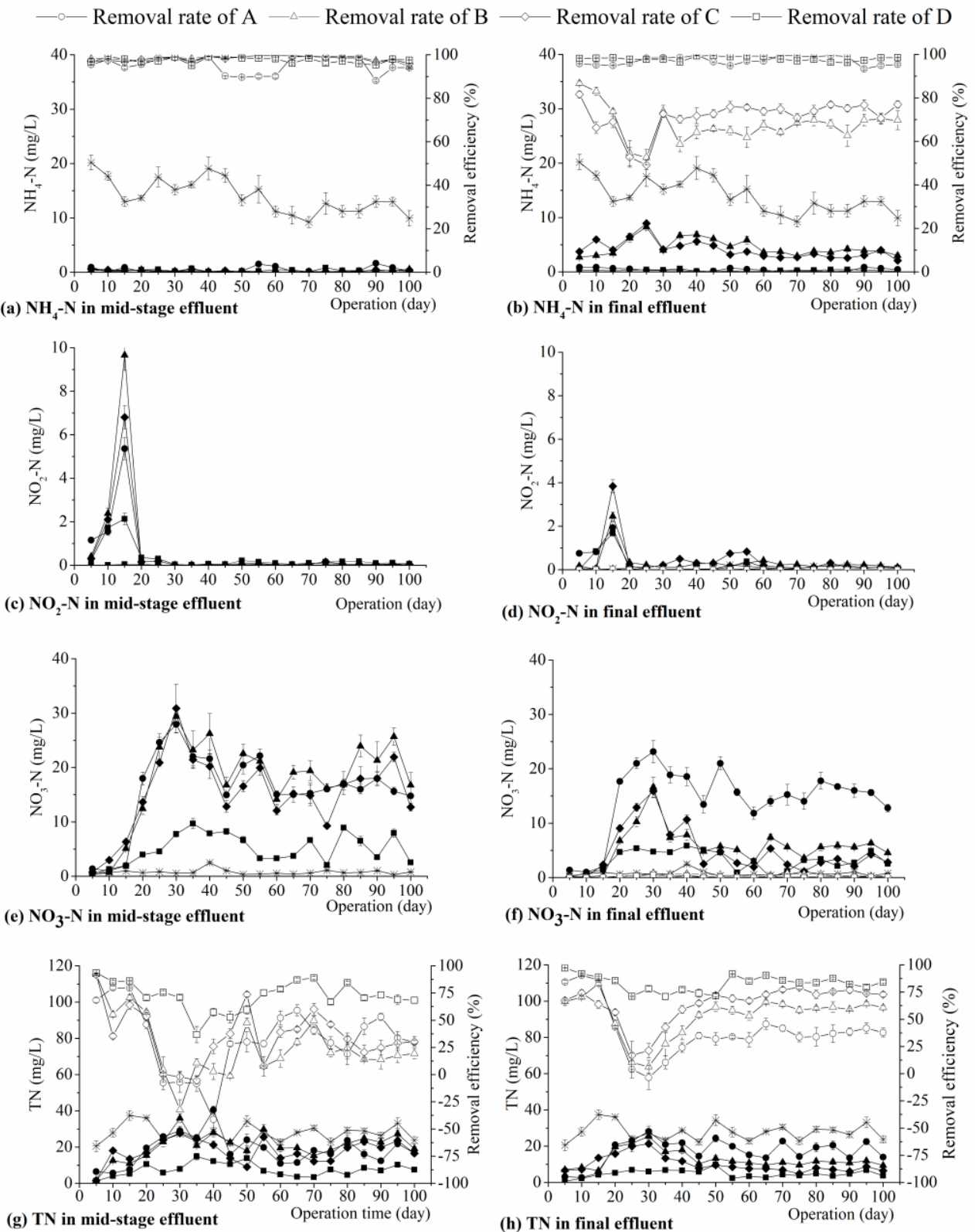

Figure 4. Nitrogen concentrations and removal efficiencies in different experimental MSL-SWI systems. (a): $\mathrm{NH}_{4}-\mathrm{N}$ in mid-stage effluent; (b) $\mathrm{NH}_{4}-\mathrm{N}$ in final effluent; (c) $\mathrm{NO}_{2}-\mathrm{N}$ in mid-stage effluent; (d) $\mathrm{NO}_{2}-\mathrm{N}$ in final effluent; (e) $\mathrm{NO}_{3}-\mathrm{N}$ in mid-stage effluent; (f) $\mathrm{NO}_{3}-\mathrm{N}$ in final effluent; (g) TN in mid-stage effluent; (h) TN in final effluent. 
As the intermediate products of biological nitrogen removal, the concentrations of $\mathrm{NO}_{2}-\mathrm{N}$ and $\mathrm{NO}_{3}-\mathrm{N}$ rose sharply and then decreased, as shown in Figure 4c-f, demonstrating the occurrence of nitrification and denitrification in each system [35]. As shown by the mid-stage effluents (Figure 4e), the concentrations of $\mathrm{NO}_{3}-\mathrm{N}$ during the first 30 days were more than $25 \mathrm{mg} \mathrm{L}^{-1}$ in MSL-SWI A, B, and C, and were even higher than the concentration of TN in the influent. This demonstrated that both the $\mathrm{NH}_{4}-\mathrm{N}$ in the sewage and that adsorbed by the zeolite were nitrified. The adsorption capacity of zeolite can be restored by nitrification, which is conducive to the long-term sustainable removal of nitrogen pollutants $[11,19,36]$. The average concentrations of $\mathrm{NO}_{3}-\mathrm{N}$ in mid-stage effluents of MSL-SWI A, B, and C were $14.62 \mathrm{mg} \mathrm{L}^{-1}, 19.45 \mathrm{mg} \mathrm{L}^{-1}$, and $15.88 \mathrm{mg} \mathrm{L}^{-1}$, respectively. The concentration of $\mathrm{NO}_{3}-\mathrm{N}$ decreased with an increasing flow rate in the MSL systems. This could be explained by the fact that more organic pollutants in the lower layers under higher flow rates provided carbon sources to promote the denitrification. In MSL-SWI D, the concentration of $\mathrm{NO}_{3}-\mathrm{N}$ in the mid-stage effluent was significantly lower than that in the other systems. This indicated incomplete nitrification, which could be explained by the deteriorated oxidation environment under a higher HLR and the "short-circuiting" of system $\mathrm{D}$ as identified based on COD and TP analyses. In the final effluents from MSL-SWI A and D (Figure 4f), the drop in $\mathrm{NO}_{3}-\mathrm{N}$ concentrations was small due to the lack of carbon sources. In contrast, the reduction of $\mathrm{NO}_{3}-\mathrm{N}$ was significant in MSL-SWI B and $\mathrm{C}$, reflecting strengthened denitrification on account of the carbon source supplement by shunt distributed wastewater $[6,28]$.

As shown in Figure 4g,h, TN removal became relatively stable after 45 days. The high TN removal efficiencies in the initial period were more dependent on substrate adsorption, but biological nitrogen removal would have become gradually more important with the growth and diversity evolution of the bacterial community [2]. In mid-stage effluents, average TN removal efficiencies were less than $40 \%$ in MSL-SWI A, B, and C, and about $90 \%$ of $\mathrm{TN}$ was composed of $\mathrm{NO}_{3}-\mathrm{N}$. The lack of carbon sources greatly restricts denitrification in the MSL systems, resulting in unsatisfactory TN purification. In the final effluent, TN removal efficiencies in MSL-SWI B and C were significantly increased by $38.36 \%$ and $36.64 \%$, respectively, which showed that although shunt distributing wastewater caused a reduction in the efficiency of $\mathrm{NH}_{4}-\mathrm{N}$ removal, nitrogen removal performance was enhanced overall because of effective denitrification processes [2,33]. Similar to $\mathrm{NO}_{3}-\mathrm{N}$ removal, the concentrations of TN were lowest in MSL-SWI D. In addition, the total TN removal efficiency indicated by the final effluent of MSL-SWI D was $9.97 \%$ higher than the mid-stage effluent, which is better than MSL-SWI A. This was in line with the short flow path in MSL-SWI D under higher HLRs, bringing about more carbon to the lower layers, thus enhancing denitrification [15].

To further understand the nitrogen removal mechanism in MSL-SWI systems, the mass balance of nitrogen was analyzed. As shown in Table 3, the nitrogen removal results were slightly different from those of water quality tests, because the mass calculation was based on 100-day operation results, including the start-up period. In the MSL section of non-shunt systems (MSL-SWI A and D), the proportions of nitrogen removal by adsorption were much higher than those by degradation. Especially for MSL-SWI D under the higher HLR, the nitrogen removed via adsorption accounted for more than $85 \%$ of the total nitrogen removal. However, opposite results were realized in the shunt systems (MSL-SWI B and C), illustrating the positive effects of shunt distribution on the biological nitrogen removal. The highest degradation proportion and the lowest adsorption proportion in MSL-SWI C also proved that intermittent operation was more conducive to nitrification and denitrification. In the SWI section, biological nitrogen removal played a more significant role in all MSLSWI systems. Comparing shunt systems with non-shunt systems, it could be inferred that shunt distributing wastewater significantly contributed to the better biodegradation. As for the whole MSL-SWI system, the best nitrogen removal performance occurred in MSL-SWI D with a continuous feeding at an HLR of $0.5 \mathrm{~m}^{3} \mathrm{~m}^{-2} \mathrm{~d}^{-1}$. However, it predominantly relied on the unsustainable process of physical and chemical absorption. 
Once the substrate had reached its adsorption saturation, the removal efficiency would decrease rapidly, causing serious pollution [33,37,38]. In MSL-SWI C, although the total nitrogen removal was not as high as in MSL-SWI D, the biological removal rate was almost tripled, benefitting from intermittent operation and shunt distributing wastewater, which provided a more sustainable and stable way to achieve high nitrogen removal in the case of domestic wastewater treatment.

Table 3. Mass balance of nitrogen in MSL-SWI systems.

\begin{tabular}{ccccccccccccc}
\hline \multirow{2}{*}{ Parameter } & \multicolumn{4}{c}{ MSL } & \multicolumn{1}{c}{ SWI } & \multicolumn{4}{c}{ MSL-SWI } \\
\cline { 2 - 14 } & $\mathbf{A}$ & $\mathbf{B}$ & $\mathbf{C}$ & $\mathbf{D}$ & $\mathbf{A}$ & $\mathbf{B}$ & $\mathbf{C}$ & $\mathbf{D}$ & A & B & C & D \\
\hline \multirow{2}{*}{ Input } & $2080.73^{1}$ & 1387.15 & 1387.15 & 3467.88 & 1376.87 & 1711.18 & 1575.91 & 940.72 & 2080.73 & 2080.73 & 2080.73 & 3467.88 \\
Output & 1376.87 & 1017.61 & 882.33 & 940.72 & 1273.96 & 951.58 & 745.09 & 588.02 & 1273.96 & 951.58 & 745.09 & 588.02 \\
& $\left(66.17^{2}\right)$ & $(73.36)$ & $(63.61)$ & $(27.13)$ & $(92.53)$ & $(55.61)$ & $(47.28)$ & $(62.51)$ & $(61.23)$ & $(45.73)$ & $(35.81)$ & $(16.96)$ \\
Adsorption & 588.23 & 145.51 & 116.82 & 2154.14 & 18.75 & 181.24 & 254.98 & 131.25 & 606.98 & 326.75 & 371.80 & 2285.39 \\
& $(28.27)$ & $(10.49)$ & $(8.42)$ & $(62.12)$ & $(1.36)$ & $(10.59)$ & $(16.18)$ & $(13.95)$ & $(29.17)$ & $(15.70)$ & $(17.87)$ & $(65.90)$ \\
Degradation & 115.62 & 224.03 & 388.00 & 373.01 & 84.16 & 578.37 & 575.84 & 221.45 & 199.79 & 802.40 & 963.84 & 594.46 \\
& $(5.56)$ & $(16.15)$ & $(27.97)$ & $(10.76)$ & $(6.11)$ & $(33.80)$ & $(36.54)$ & $(23.54)$ & $(9.60)$ & $(38.56)$ & $(46.32)$ & $(17.14)$ \\
\hline
\end{tabular}

${ }^{1}$ Mean value of nitrogen load (mg/day). ${ }^{2}$ Values in the round brackets represent the mean proportion of the output nitrogen to the input nitrogen $(\%)$.

\subsection{The Association between Nitrogen Removal and Functional Genes}

The abundance of nitrogen functional genes in the four MSL-SWI systems is shown in Figure 5. The gene amoA, which catalyzes the oxidation of $\mathrm{NH}_{4}-\mathrm{N}$ to $\mathrm{NO}_{2}-\mathrm{N}$, is thought to be rate-limiting in nitrification [39-41]. A reduction in the abundance of amoA genes was found between sections of MSL-SWI A and D in the order PLs $>$ SMBs $>$ SWI reactors. However, in MSL-SWI B and C, the abundance of amoA genes initially peaked in the PLs, then decreased in the SMBs, and, finally, slightly increased in the SWI sections. This showed how shunt distributing wastewater enhanced the growth of nitrogen-removing bacteria and improved the associated enzyme activity [42]. In addition, the abundances of the amoA gene in the SMBs and the SWI sections of MSL-SWI C were significantly increased compared to MSL-SWI B, indicating a positive influence of intermittent operation on nitrification [34]. The opposite trend was found in the PLs of MSL-SWI B and C; PLs that can have higher permeability were detrimental to the water-holding capacity of MSL-SWI C and led to shorter sewage retention times under a higher flow rate, which was not conducive to nitrification. The observations were consistent with the analysis of nitrogen removal reported in Section 3.3. Furthermore, the low abundance of amoA genes observed in MSL-SWI D also proved incomplete nitrification due to the unfavorable oxygen environment and short-circuiting under the higher HLR.

With respect to denitrification, nitrite reductase, as the product of the genes nirK and nirS, is the limiting factor [43]. Furthermore, $\mathrm{N}_{2} \mathrm{O}$ reductase, encoded by nosZ genes, indicates complete biological denitrification. In this study, the abundance of nirK, nirS, and nosZ genes decreased in the order PLs > SMBs > SWI sections in four systems, which probably reflected the progressive reduction in pollutants. The higher water flow in the SMBs under higher HLRs might lead to a higher abundance of these genes in MSL-SWI A and D compared to MSL-SWI B and C. Their low abundance in the PLs of MSL-SWI D also reflected the fact that systems overloaded with pollutants can inhibit bacterial growth. Remarkably, the low abundance of nosZ genes in the SWI section indicated incomplete denitrification, which will cause the release of the greenhouse gases $\mathrm{NO}$ and $\mathrm{N}_{2} \mathrm{O}$, requiring further investigation. 


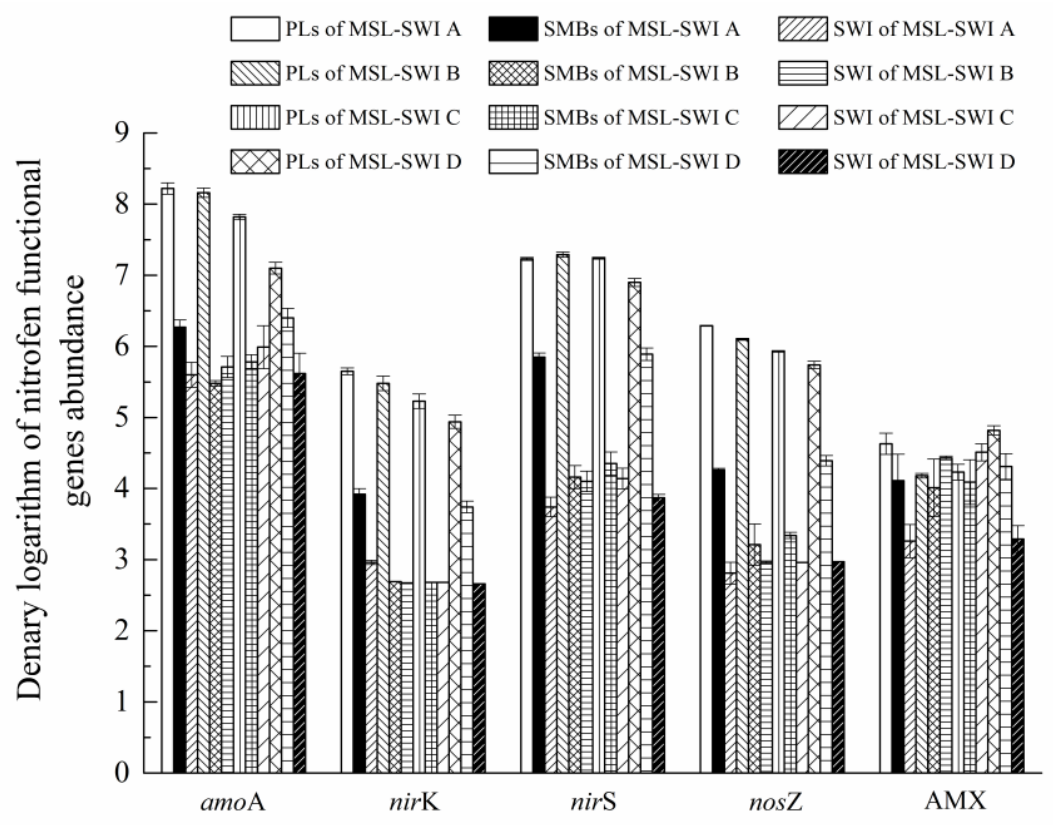

Figure 5. The abundance of nitrogen functional genes in PLs, SMBs, and SWI sections in four MSL-SWI systems.

AMX is regarded as the marker of anaerobic ammonium oxidation (anammox) that converts $\mathrm{NH}_{4}-\mathrm{N}$ and $\mathrm{NO}_{2}-\mathrm{N}$ to $\mathrm{N}_{2}$ under anoxic conditions, which is of great significance for nitrogen removal during sewage treatment [44]. As shown in Figure 5, the abundance of AMX in the PLs increased with increasing HLRs. This could be interpreted as showing the strong $\mathrm{NH}_{4}-\mathrm{N}$ adsorption ability of zeolite, which provided more $\mathrm{NH}_{4}-\mathrm{N}$ substrate for nitrifying bacteria under high HLRs. In MSL-SWI B and C, the abundance of AMX in the SWI sections was higher in the PLs and the SMBs. This resulted from the saturated conditions and the shunt distributed wastewater. Compared to MSL-SWI C, the higher abundance of AMX in MSL-SWI B also demonstrated that the environment in system B was more beneficial to anaerobic processes.

Table 4 shows the Pearson correlation coefficients for nitrogen removal rates and the abundance of functional genes. In the PLs of the MSL sections, the $\mathrm{NO}_{3}-\mathrm{N}$ removal rate was negatively correlated with the abundances of amoA $(p<0.05)$. A high abundance of amo A genes has been identified as a sign of sufficient nitrification, indicating the production of $\mathrm{NO}_{3}-\mathrm{N}$ [39]. The positive correlation between the $\mathrm{NO}_{2}-\mathrm{N}$ purification rate and nirK was also significant $(p<0.05)$, which demonstrated that denitrification in the PLs was primarily facilitated by nirK genes. This is consistent with other studies showing that, although the abundance of nirS genes was higher than nirK genes, nirK genes are more essential for denitrification in aerobic conditions. However, even if the denitrification functionality of nirS genes in the PLs was low, $\mathrm{NO}_{3}-\mathrm{N}$ and $\mathrm{NO}_{2}-\mathrm{N}$ acted as the substrates for denitrification and accounted for more than $80 \%$ of the $\mathrm{TN}$ in the mid-stage effluent. This contributed to a higher abundance of nirS genes at this stage, and resulted in a negative correlation between $\mathrm{TN}$ removal rate and nirS. $\mathrm{N}_{2} \mathrm{O}$ reductase, encoded by the nos $\mathrm{Z}$ genes, was influenced by the reduction and removal rate of $\mathrm{NO}_{2}-\mathrm{N}$, shown by their positive correlation $(p<0.05)$. In the SMBs of the MSL sections, positive correlations between the $\mathrm{NH}_{4}-\mathrm{N}$ removal rates and the abundance of amoA, nirS, and nosZ genes and AMX were observed $(p<0.05)$. This indicated that the removal of $\mathrm{NH}_{4}-\mathrm{N}$ was mainly influenced by nitrification and anammox rather than adsorption given the lower ion exchange capacity of the soil compared to zeolite. For nirS and nosZ, the positive correlations might have resulted from substrate supplementation by nitrification. The positive correlations between denitrification genes (nirK, nirS, and nosZ) and $\mathrm{NO}_{3}-\mathrm{N}, \mathrm{NO}_{2}-\mathrm{N}$, and $\mathrm{TN}$ removal implied that denitrification in the MSL systems occurred in the SMBs, but the effects were not significant $(p>0.05)$. However, TN removal rates were positively correlated with $\operatorname{AMX}(p<0.05)$. Nitrification coupled with anammox 
might, therefore, be the primary mechanism of biological nitrogen removal in MSL systems. In the SWI systems, positive correlations between amo A genes and the $\mathrm{NH}_{4}-\mathrm{N}$ removal rate, between nirS genes and the $\mathrm{NO}_{3}-\mathrm{N}$ removal rate, and between nirS genes and the TN removal rate demonstrated that the nitrogen removal was driven by biological nitrification and denitrification. The unusual phenomenon of the $\mathrm{NO}_{2}-\mathrm{N}$ removal rate being negatively correlated with the abundance of nirS genes might result from the omission of $\mathrm{NO}_{2}-\mathrm{N}$ (produced by the reduction of $\mathrm{NO}_{3}-\mathrm{N}$ ) from the first denitrification process.

Table 4. Pearson correlation coefficients between nitrogen removal rates and functional genes in different MSL-SWI media.

\begin{tabular}{|c|c|c|c|c|c|c|c|c|c|c|c|c|}
\hline \multirow{2}{*}{$\begin{array}{l}\text { Para- } \\
\text { Meter }\end{array}$} & \multicolumn{4}{|c|}{ PLs } & \multicolumn{4}{|c|}{ SMBs } & \multicolumn{4}{|c|}{ SWI } \\
\hline & $\mathrm{NH}_{4}-\mathrm{N}$ & $\mathrm{NO}_{3}-\mathrm{N}$ & $\mathrm{NO}_{2}-\mathrm{N}$ & TN & $\mathrm{NH}_{4}-\mathrm{N}$ & $\mathrm{NO}_{3}-\mathrm{N}$ & $\mathrm{NO}_{2}-\mathrm{N}$ & TN & $\mathrm{NH}_{4}-\mathrm{N}$ & $\mathrm{NO}_{3}-\mathrm{N}$ & $\mathrm{NO}_{2}-\mathrm{N}$ & $\mathrm{TN}$ \\
\hline amoA & -0.174 & -0.958 & 0.872 & -0.685 & 0.968 & 0.571 & 0.077 & 0.939 & 0.963 & 0.682 & -0.747 & 0.736 \\
\hline nirK & 0.058 & -0.907 & 0.963 & -0.510 & 0.938 & 0.021 & 0.605 & 0.592 & -0.139 & -0.795 & 0.493 & -0.708 \\
\hline nirs & -0.708 & -0.912 & 0.433 & -0.982 & 0.999 & 0.372 & 0.306 & 0.838 & 0.640 & 0.981 & -0.965 & 0.997 \\
\hline nosZ & 0.136 & -0.876 & 0.978 & -0.442 & 0.985 & 0.513 & 0.158 & 0.912 & 0.180 & 0.799 & -0.501 & 0.714 \\
\hline AMX & 0.950 & 0.426 & 0.713 & 0.916 & 0.980 & 0.747 & 0.387 & 0.991 & 0.679 & 0.814 & -0.919 & 0.923 \\
\hline
\end{tabular}

\subsection{Cost Analysis}

As MSL-SWI systems are mainly composed of local and waste materials, such as soil, bio-ceramic, and cinder, the cost of construction is comparatively low. To construct an MSLSWI system with a domestic sewage treatment capacity of $100 \mathrm{~m}^{3} \mathrm{~d}^{-1}$, the area required is around $300 \mathrm{~m}^{2}$, with a depth of $0.5 \mathrm{~m}$ for both MSL and SWI sections. Sewage from the storage tank is generally distributed evenly onto the top zeolite layer in MSL sections through a set of perforated pipes. Shunt distributed wastewater mixed with the effluent of MSL sections is then transported into the bottom of the systems while the outlet is located at the top of SWI sections to ensure the anaerobic environment. It is necessary to ensure a uniform distribution of wastewater across the facility. Regarding to the preparation of substrate materials, if we assume that half of the MSL system is composed of zeolite $\left(75 \mathrm{~m}^{3}\right)$, around 45 tonnes of zeolite would be required at a price of USD 20 tonne $\mathrm{e}^{-1}$, for a total price of USD 900 in China. The bulk density of SMBs is around $1.2 \mathrm{~g} \mathrm{~cm}^{-3}$. The weight of SMBs is around 90 tonnes, out of which $60 \%$ is soil (around 54 tonnes), $30 \%$ is cinder (around 27 tonnes), and 10\% is bio-ceramic (around 9 tonnes). The bulk density of the SWI sections is around $1.4 \mathrm{~g} \mathrm{~cm}^{-3}$. Similarly, the weight of SWI is around 210 tonnes, out of which $70 \%$ is soil (around 147 tonnes), $20 \%$ is cinder (around 42 tonnes), and 10\% is bio-ceramic (around 21 tonnes). The price for bio-ceramic is around USD 80 tonne $^{-1}$ in China. The cinder, as industrial waste, is usually free. Therefore, the whole cost for constructing such an MSL-SWI system can be about USD 10,000 in China. In addition, as an ecological technology, no power or only micro power is necessary for sewage transportation and distribution in the MSL-SWI system. The main types of maintenance, including grid cleaning and clogging inspection, are uncomplicated and easy to implement. Most of the sludge can be decomposed inside the systema, and the substrates from the used systems may be applied for agricultural addition as they are rich in nutrients, such as $\mathrm{NH}_{4}-\mathrm{N}, \mathrm{P}, \mathrm{Fe}$, and Ca. Nevertheless, a careful assessment should be conducted for the reusability of the soil since it may contain unconventional containments (such as environmental hormones) which can cause potential harm to the environment and ecology [29].

\section{Conclusions}

The performance of domestic sewage treatments and the mechanisms of nitrogen removal by a novel, integrated MSL-SWI system were studied using pilot-scale experiments. The lowest TN concentrations occurred in MSL-SWI D operated with continuous feeding at an HLR of $0.5 \mathrm{~m}^{3} \mathrm{~m}^{-2} \mathrm{~d}^{-1}$. However, nitrogen pollutants were mainly removed via unsustainable absorption processes without sufficient nitrification. Therefore, MSL-SWI systems with intermittent operation and shunt distributed wastewater have been proved to be optimal, due to the successful functionalized partitioning. In this system, the upper MSL section facilitates the removal of organic matter, provides sufficient nitrification, and 
prevents the system from becoming clogged by mitigating the accumulation of pollutants. The SWI section further purifies the sewage by removing residual pollutants and acts as a denitrification reactor to improve nitrogen removal. Stable removal efficiencies of $93.41 \%$ for $\mathrm{COD}, 97.91 \%$ for $\mathrm{TP}, 74.02 \%$ for $\mathrm{NH}_{4}-\mathrm{N}$, and $73.56 \%$ for $\mathrm{TN}$ were obtained with an HLR of $0.3 \mathrm{~m}^{3} \mathrm{~m}^{-2} \mathrm{~d}^{-1}$. Based on the analysis of nitrogen transformation and functional genes, both nitrification combined with anammox in the MSL systems and nitrification coupled with denitrification in the SWI systems were found to be key mechanisms for the sustainable nitrogen removal in MSL-SWI systems. The systems offer promise for efficient and sustainable domestic sewage treatment under high HLRs.

Author Contributions: Conceptualization, D.L., X.W. and L.C.; methodology, D.L., X.W. and L.C.; software, D.L.; validation, D.L.; formal analysis, D.L.; investigation, D.L., Z.Z., Y.L. and X.L.; resources, X.W.; data curation, D.L.; writing-original draft preparation, D.L.; writing-review and editing, L.C. and X.W.; visualization, D.L.; supervision, X.W. and L.C.; project administration, X.W. and L.C.; funding acquisition, X.W. and L.C. All authors have read and agreed to the published version of the manuscript.

Funding: This research was funded by the National Key Project on Prevention and Control of Water Pollution from the Ministry of Ecology and Environment, China, grant number 2017ZX07203-005.

Institutional Review Board Statement: Not applicable.

Informed Consent Statement: Informed consent was obtained from all subjects involved in the study.

Data Availability Statement: Data available in a publicly accessible repository that does not issue DOIs Publicly available datasets were analyzed in this study. This data can be found here: [Link: https: / /entuedu-my.sharepoint.com/:f:/g/personal/dan005_e_ntu_edu_sg/ElVKCbFk-0tDo1u0GWHuu8 wBLI2CLH0tJKk908B3kuNx5Q?e=JZjUje/Accession number: 427835].

Acknowledgments: We acknowledge the financial support from the National Key Project on Prevention and Control of Water Pollution from the Ministry of Ecology and Environment, China (2017ZX07203-005).

Conflicts of Interest: The authors declare no conflict of interest. The funders had no role in the design of the study; in the collection, analyses, or interpretation of data; in the writing of the manuscript, or in the decision to publish the results.

\section{Appendix A}

Table A1. Fundamental properties of red clay.

\begin{tabular}{cccccc}
\hline Item & $\begin{array}{c}\text { Organic Matter } \\
\text { Content }(\%)\end{array}$ & $\begin{array}{c}\text { Nitrogen Content } \\
(\mathbf{m g} / \mathbf{K g})\end{array}$ & $\begin{array}{c}\text { Phosphorus Content } \\
(\mathbf{m g} / \mathbf{K g})\end{array}$ & $\begin{array}{c}\text { Potassium Content } \\
(\mathbf{m g} / \mathbf{K g})\end{array}$ & - \\
\hline Red clay & 0.2 & 38 & - & 52 & 6.5 \\
\hline
\end{tabular}

Table A2. Fundamental properties of zeolite.

\begin{tabular}{cccccc}
\hline Item & Hardness & Pore Diameter (AI) & Specific Surface Area $\left(\mathbf{m}^{2} / \mathbf{g}\right)$ & Si/Al Ratio & Thermal Stability $\left({ }^{\circ} \mathbf{C}\right)$ \\
\hline Zeolite & $3-4$ & $3.51-4$ & $230-320$ & 6.5 & 750 \\
\hline
\end{tabular}

Table A3. Fundamental properties of bio-ceramic.

\begin{tabular}{|c|c|c|c|c|c|}
\hline \multirow{2}{*}{ Item } & \multirow{2}{*}{ Porosity (\%) } & \multirow{2}{*}{ Specific Surface Area $\left(\mathrm{m}^{2} / \mathrm{g}\right)$} & \multicolumn{3}{|c|}{ Chemical Composition (\%) } \\
\hline & & & $\mathrm{SiO}_{2}$ & $\mathrm{Al}_{2} \mathrm{O}_{3}$ & $\mathrm{Fe}_{2} \mathrm{O}_{3}$ \\
\hline Bio-ceramic & $56 \%$ & 0.98 & 65 & $18-22$ & $6-8$ \\
\hline
\end{tabular}


Table A4. Fundamental properties of cinder.

\begin{tabular}{|c|c|c|c|c|c|}
\hline \multirow{2}{*}{ Item } & \multirow{2}{*}{ Specific Surface Area $\left(\mathrm{m}^{2} / \mathrm{g}\right)$} & \multicolumn{4}{|c|}{ Chemical Composition (\%) } \\
\hline & & $\mathrm{SiO}_{2}$ & $\mathrm{Al}_{2} \mathrm{O}_{3}$ & $\mathrm{FeO}_{\mathrm{n}}$ & $\mathrm{CaO}$ \\
\hline Cinder & $0.27-0.32$ & 40 & 14 & 18 & 22 \\
\hline
\end{tabular}

\section{References}

1. Wu, H.; Fan, J.; Zhang, J.; Ngo, H.H.; Guo, W.; Hu, Z.; Liang, S. Decentralized domestic wastewater treatment using intermittently aerated vertical flow constructed wetlands: Impact of influent strengths. Bioresour. Technol. 2015, 176, 163-168. [CrossRef]

2. Yang, Y.; Zhan, X.; Wu, S.; Kang, M.; Guo, J.; Chen, F. Effect of hydraulic loading rate on pollutant removal efficiency in subsurface infiltration system under intermittent operation and micro-power aeration. Bioresour. Technol. 2016, 205, 174-182. [CrossRef]

3. Ho, C.C.; Wang, P.H. Efficiency of a multi-soil-layering system on wastewater treatment using environment-friendly filter materials. Int. J. Env. Res. Public Health 2015, 12, 3362-3380. [CrossRef]

4. Hatt, B.E.; Fletcher, T.D.; Deletic, A. Treatment performance of gravel filter media: Implications for design and application of stormwater infiltration systems. Water Res. 2007, 41, 2513. [CrossRef]

5. Li, Y.H.; Li, H.B.; Xu, X.Y.; Gong, X.; Zhou, Y.C. Application of subsurface wastewater infiltration system to on-site treatment of domestic sewage under high hydraulic loading rate. Water Sci. Eng. 2015, 8, 49-54. [CrossRef]

6. Pan, J.; Yuan, F.; Yu, L.; Huang, L.; Fei, H.; Cheng, F.; Zhang, Q. Performance of organics and nitrogen removal in subsurface wastewater infiltration systems by intermittent aeration and shunt distributing wastewater. Bioresour. Technol. 2016, 211, 774-778. [CrossRef]

7. Zhang, L.; Yang, J. The influence of hydraulic loading on biofilm properties in a subsurface wastewater infiltration system. Arch. Environ. Prot. 2016, 42, 70-79. [CrossRef]

8. Luanmanee, S.; Attanandana, T.; Masunaga, T.; Wakatsuki, T. The efficiency of a multi-soil-layering system on domestic wastewater treatment during the ninth and tenth years of operation. Ecol. Eng. 2002, 18, 185-199. [CrossRef]

9. Li, H.; Li, Y.; Sun, T.; Wang, X. The use of a subsurface infiltration system in treating campus sewage under variable loading rates. Ecol. Eng. 2012, 38, 105-109. [CrossRef]

10. Sato, K.; Masunaga, T.; Wakatsuki, T. Characterization of Treatment Processes and Mechanisms of COD, Phosphorus and Nitrogen Removal in a Multi-Soil-Layering System. Soil Sci. Plant. Nutr. 2010, 51, 213-221. [CrossRef]

11. Sato, K.; Iwashima, N.; Wakatsuki, T.; Masunaga, T. Quantitative evaluation of treatment processes and mechanisms of organic matter, phosphorus, and nitrogen removal in a multi-soil-layering system. Soil Sci. Plant. Nutr. 2011, 57, 475-486. [CrossRef]

12. Shen, J.; Huang, G.; An, C.; Song, P.; Xin, X.; Yao, Y.; Zheng, R. Biophysiological and factorial analyses in the treatment of rural domestic wastewater using multi-soil-layering systems. J. Environ. Manag. 2018, 226, 83-94. [CrossRef] [PubMed]

13. Zhang, L.Y.; Ye, Y.B.; Wang, L.J.; Xi, B.D.; Wang, H.Q.; Li, Y. Nitrogen removal processes in deep subsurface wastewater infiltration systems. Ecol. Eng. 2015, 77, 275-283. [CrossRef]

14. Song, P.; Huang, G.; An, C.; Shen, J.; Zhang, P.; Chen, X.; Shen, J.; Yao, Y.; Zheng, R.; Sun, C. Treatment of rural domestic wastewater using multi-soil-layering systems: Performance evaluation, factorial analysis and numerical modeling. Sci. Total Environ. 2018, 644, 536-546. [CrossRef]

15. Luo, W.; Yang, C.; He, H.; Zeng, G.; Yan, S.; Cheng, Y. Novel two-stage vertical flow biofilter system for efficient treatment of decentralized domestic wastewater. Ecol. Eng. 2014, 64, 415-423. [CrossRef]

16. Masunaga, T.; Sato, K.; Mori, J.; Shirahama, M.; Kudo, H.; Wakatsuki, T. Characteristics of wastewater treatment using a multi-soil-layering system in relation to wastewater contamination levels and hydraulic loading rates. Soil Sci. Plant. Nutr. 2010, 53, 215-223. [CrossRef]

17. Latrach, L.; Ouazzani, N.; Hejjaj, A.; Zouhir, F.; Mahi, M.; Masunaga, T.; Mandi, L. Optimization of hydraulic efficiency and wastewater treatment performances using a new design of vertical flow Multi-Soil-Layering (MSL) technology. Ecol. Eng. 2018, 117, 140-152. [CrossRef]

18. Guo, J.; Zhou, Y.; Jiang, S.; Chen, C. Feasibility investigation of a multi soil layering bioreactor for domestic wastewater treatment. Environ. Technol. 2019, 40, 2317-2324. [CrossRef]

19. An, C.J.; McBean, E.; Huang, G.H.; Yao, Y.; Zhang, P.; Chen, X.J.; Li, Y.P. Multi-soil-layering systems for wastewater treatment in small and remote communities. J. Environ. Inform. 2016, 27, 131-144. [CrossRef]

20. Wu, H.; Wei, C.; Wu, W. Study on nitrogen removal performance and mechanism of external carbon source added two-stages multi-soil-layering systems for low pollutant loading wastewater treatment. Huanjing Kexue Xиebao 2016, 36, 4392-4399.

21. Wei, C.J.; Wu, W.Z. Performance of single-pass and by-pass multi-step multi-soil-layering systems for low-(C/N)-ratio polluted river water treatment. Chemosphere 2018, 206, 579-586. [CrossRef]

22. Song, P.; Huang, G.; Hong, Y.; An, C.; Xin, X.; Zhang, P. A biophysiological perspective on enhanced nitrate removal from decentralized domestic sewage using gravitational-flow multi-soil-layering systems. Chemosphere 2020, 240, 124868. [CrossRef] [PubMed]

23. APHA. Standard Methods for the Examination of Water and Wastewater; American Public Health Association/American Water Works Association: Washington, DC, USA, 2003. 
24. Zhang, G.L.; Gong, Z.T. Soil Survey Laboratory Methods; Science Press: Beijing, China, 2012. (In Chinese)

25. Ji, G.; Zhi, W.; Tan, Y. Association of nitrogen micro-cycle functional genes in subsurface wastewater infiltration systems. Ecol. Eng. 2012, 44, 269-277. [CrossRef]

26. Latrach, L.; Ouazzani, N.; Masunaga, T.; Hejjaj, A.; Bouhoum, K.; Mahi, M.; Mandi, L. Domestic wastewater disinfection by combined treatment using multi-soil-layering system and sand filters (MSL-SF): A laboratory pilot study. Ecol. Eng. 2016, 91, 294-301. [CrossRef]

27. Vymazal, J.; Kröpfelová, L. Removal of organics in constructed wetlands with horizontal sub-surface flow: A review of the field experience. Sci. Total Environ. 2009, 407, 3911-3922. [CrossRef]

28. Pan, J.; Yuan, F.; Zhang, Y.; Huang, L.; Yu, L.; Zheng, F.; Cheng, F.; Zhang, J. Pollutants removal in subsurface infiltration systems by shunt distributing wastewater with/without intermittent aeration under different shunt ratios. Bioresour. Technol. 2016, 218, 101-107. [CrossRef]

29. Xin, C.; Luo, A.C.; Sato, K.; Wakatsuki, T.; Masunaga, T. An introduction of a multi-soil-layering system: A novel green technology for wastewater treatment in rural areas. Water Environ. J. 2010, 23, 255-262.

30. Arias, C.A.; Del, B.M.; Brix, H. Phosphorus removal by sands for use as media in subsurface flow constructed reed beds. Water Res. 2001, 35, 1159-1168. [CrossRef]

31. Molle, P.; Liénard, A.; Grasmick, A.; Iwema, A. Effect of reeds and feeding operations on hydraulic behaviour of vertical flow constructed wetlands under hydraulic overloads. Water Res. 2006, 40, 606-612. [CrossRef]

32. Zhang, J.; Huang, X.; Liu, C.; Shi, H.; Hu, H. Nitrogen removal enhanced by intermittent operation in a subsurface wastewater infiltration system. Ecol. Eng. 2005, 25, 419-428. [CrossRef]

33. Pan, J.; Yu, L.; Li, G.Z.; Huang, L.L.; Jin, H.T. Characteristics of microbial populations and enzyme activities in non-shunt and shunt subsurface wastewater infiltration systems during nitrogen removal. Ecol. Eng. 2013, 61, 127-132. [CrossRef]

34. Li, Y.; Li, H.; Sun, T.; Wang, X. Study on nitrogen removal enhanced by shunt distributing wastewater in a constructed subsurface infiltration system under intermittent operation mode. J. Hazard. Mater. 2011, 189, 336-341. [CrossRef] [PubMed]

35. Xin, W.; Sun, T.H.; Li, H.B.; Li, Y.H.; Jing, P. Nitrogen removal enhanced by shunt distributing wastewater in a subsurface wastewater infiltration system. Ecol. Eng. 2010, 36, 1433-1438.

36. Guan, Y.; Zhang, Y.; Zhong, C.N.; Huang, X.F.; Fu, J.; Zhao, D. Effect of operating factors on the contaminants removal of a soil filter: Multi-soil-layering system. Environ. Earth Sci. 2015, 74, 2679-2686. [CrossRef]

37. Carrera, J.; Baeza, J.A.; Vicent, T.; Lafuente, J. Biological nitrogen removal of high-strength ammonium industrial wastewater with two-sludge system. Water Res. 2003, 37, 4211-4221. [CrossRef]

38. Zou, J.L.; Dai, Y.; Sun, T.H.; Li, Y.H.; Li, G.B.; Li, Q.Y. Effect of amended soil and hydraulic load on enhanced biological nitrogen removal in lab-scale SWIS. J. Hazard. Mater. 2009, 163, 816-822. [CrossRef]

39. Zhi, W.; Ji, G. Quantitative response relationships between nitrogen transformation rates and nitrogen functional genes in a tidal flow constructed wetland under C/N ratio constraints. Water Res. 2014, 64, 32-41. [CrossRef] [PubMed]

40. Kowalchuk, G.A.; Stephen, J.R. Ammonia-Oxidizing Bacteria: A Model for Molecular Microbial Ecology. Annu. Rev. Microbiol. 2001, 55, 485. [CrossRef]

41. Dionisi, H.M.; Layton, A.C.; Gerda, H.; Gregory, I.R.; Robinson, K.G.; Sayler, G.S. Quantification of Nitrosomonas oligotrophalike ammonia-oxidizing bacteria and Nitrospira spp. from full-scale wastewater treatment plants by competitive PCR. Appl. Environ. Microbiol. 2002, 68, 245. [CrossRef]

42. Pan, J.; Qi, S.; Sun, Y.; Jiang, Y.; Zhao, N.; Huang, L.; Sun, Y. Nitrogen removal and nitrogen functional gene abundances in three subsurface wastewater infiltration systems under different modes of aeration and influent C/N ratios. Bioresour. Technol. 2017, 241, 1162. [CrossRef]

43. Braker, G.; Kp, F.A.W. Development of PCR primer systems for amplification of nitrite reductasegenes (nirK and nirS) to detect denitrifying bacteria in environmentalsamples. Appl. Environ. Microbiol. 1998, 64, 3769-3775. [CrossRef] [PubMed]

44. Ikuo, T.; Yuji, O.; Tomonori, K.; Hisashi, S.; Satoshi, O. Development of high-rate anaerobic ammonium-oxidizing (anammox) biofilm reactors. Water Res. 2007, 41, 1623-1634. 